\title{
TOWARDS UNITY AND AUTONOMY: THE BELGIAN MEDICAL PROFESSION IN THE NINETEENTH CENTURY
}

\author{
by
}

\author{
R. M. J. SCHEPERS *
}

\section{INTRODUCTION}

Sociological literature on the professions has focused on the fact that they are characterized by a high degree of autonomy, that is, legitimated control over their organization and terms of work. ' The development of such autonomy must, therefore, be seen as central to the process of professionalization. However, the problems which beset sociologists in ascertaining whether professional autonomy has diminished in recent years are similar to those of establishing when and how the medical profession in various countries, in this particular case Belgium, became autonomous in the first place. Too often conclusions have been drawn on the basis of changes in legislation. But there is more to the concept. Different dimensions need to be distinguished: economic autonomy, the right of doctors to determine their remuneration; political autonomy, the right of doctors to make policy decisions as the legitimate experts on health matters; and clinical or technical autonomy, the right of the profession to set its own standards and control clinical performance, exercised, for example, through clinical freedom at the bedside, control over recruitment and training, and collegial control over discipline and malpractice. ${ }^{2}$

We normally use the term "medical profession" to describe all those persons who hold a formal qualification to practise medicine. With respect to this definition, two points should be made. First, in the early nineteenth century, those who made a living providing medical care not only exhibited few of the characteristics of the modern medical profession but, equally important, did not constitute a single occupational group. To apply the term "profession" in the early nineteenth century tends to mask the significance of the major changes which occurred in the structure of medical practice later in the century. ${ }^{3}$ Second, a profession is more than an aggregate of individual practitioners. It is a social entity

\footnotetext{
* R. M. J. Schepers, MSc, PhD, Department of Health Care Policy and Management, Erasmus University Rotterdam, P.O. Box 1738, 3000 DR Rotterdam, The Netherlands.

I am grateful to Dr Hilary Marland for comments on an earlier version of this paper.

' Eliot Freidson, Profession of medicine. A study of the sociology of applied knowledge, New York, Dodd, Mead \& Co, 1973, p. 71.

2 Mary Ann Elston, 'The politics of professional power: medicine in a changing health service', in J. Gabe, M. Calnan, and M. Bury (eds), The sociology of the health service, London, Routledge, 1991, pp. 58-88, on p. 61-2.

${ }^{3}$ Ivan Waddington, The medical profession in the industrial revolution, Dublin, Gill and Macmillan Humanities Press, 1984, p. 176.
} 


\section{R. M. J. Schepers}

organized by formal associations whose officers negotiate licensing laws, standards, and the like, thereby establishing the framework within which its individual members work. ${ }^{4}$

The following analysis takes as its main focus the evolution of medical autonomy in Belgium in the nineteenth century. In particular, the development of professional control over entry to the profession and collegial control over discipline will be examined. The emphasis is on the profession as an organized social entity. I will illustrate, first, that the Belgian medical profession became legally unified at a relatively early stage. Second, it will be shown how control over training and discipline was exercised by an élite segment within the profession. It is not easy to define what is meant by "élite". Certainly the élite included members of officially constituted bodies, such as the Académie Royale de Médecine, the Conseil Supérieur d'Hygiène Publique, and the provincial medical boards. This group also held important teaching positions at the four Belgian universities. Its members enjoyed high prestige and wealth from their academic and bureaucratic positions and were able to attract an affluent clientele. Their perspective on the needs of the profession was different to that of common practitioners. Third, this internal stratification of the medical profession will be shown to be crucial to an understanding of the professionalization process among Belgian doctors in the nineteenth century; it was the basis of a reform movement which brought together rank-and-file members. It will be suggested that this internal division helps to explain the differences in professional organization between Belgium and the Netherlands, countries sharing a common legal background. Last but not least, it will be suggested that, despite the early establishment of a monopoly for medical practitioners and the early legal unification of the Belgian medical profession, and despite the early institutionalization of professional control of medical practice, it was only towards the end of the nineteenth century that the institutional structure of the Belgian medical profession began to emerge in a form recognizable to us today. Essential in this respect is the fact that the supervision of medical practice shifted from the élite to the professional associations.

The first two sections of this article survey the formal regulations regarding medical practice during the ancien régime, the French Revolution, and under Dutch government. Due to the sparsity of good historical studies, our knowledge of the period before 1815 is almost exclusively taken from the formal regulations of the urban-based medical colleges and guilds. In many respects the Belgian organization of the medical profession resembles that of other pre-industrial European countries. One aspect was, however, strikingly different, namely the fact that formal regulations changed twice within a brief period of time. This contributed to a greater internal heterogeneity than in neighbouring countries, for example, the Netherlands. Moreover, it is important to note that Belgian medical practitioners were probably not in a position to influence the development of the medical laws of 1803 and 1818. In the second section, we will concentrate on developments in education, legal position and professional organization after Belgian independence in 1830 .

\section{MEDICAL ORGANIZATION IN THE EIGHTEENTH CENTURY AND DURING THE FRENCH REVOLUTION}

As seems to have been characteristic of early modern Europe, three separately organized medical groups can be distinguished in Belgium: the doctors and licentiates in medicine, the

\footnotetext{
${ }^{4}$ Eliot Freidson, 'The reorganization of the medical profession', Medical Care Review, 1985, 42: 11-35.
} 
surgeons, and the apothecaries. Each of these groups was differentiated from the others in terms of the legal status of its members and the education and training which they had received. They performed different functions: the doctors and licentiates in medicine diagnosed complaints, prescribed treatments and attended and advised; the surgeons offered craft and manual skills, and the apothecaries provided material agents supposed to cure. Moreover, there were differences in corporate organization. The formal regulations suggested a hierarchy, with the doctors and licentiates in medicine at the top, and the surgeons, especially the rural surgeons, at the bottom. This hierarchy was reflected in the rules governing the practice of the different groups. For example, a medical prescription was needed for bleeding and purging, and when serious and complicated surgical operations were carried out, the doctor's presence was required. A medical prescription was also needed for the sale of compounded drugs, and doctors were supposed to supervise the quality of the drugs. As in other European countries, ${ }^{5}$ there are strong indications that the formal divisions did not coincide with divisions in day-to-day practice. Rural surgeons in particular, the most important practitioners in the countryside, combined the various branches of medicine, including pharmacy. Some also engaged in non-medical activities to supplement their meagre incomes. ${ }^{6}$ It is probable that the formal medical hierarchy reflected not only or not mainly a division of labour within the profession, but also a form of social hierarchy. As Pickstone suggests,

the prestige of a physician in a small town derived from his family background, education and social contacts; he was part of the local authority structure. His situation may not have endeared him to those members of the lower orders whose acceptance of authority was forced, but it did bind him to those rather higher in the scale who, in any case, were the only ones able to pay for his services. ${ }^{7}$

According to Waddington, a number of general points concerning the structure of the market for medical care, which are not unique to pre-industrial England, can be made with a reasonable degree of certainty. ${ }^{8}$ First, the demand for qualified health care was a relatively small one, and tended to be highly concentrated amongst the wealthier sections of the community. ${ }^{9}$ Second, it should not be assumed that even those who could afford to pay for the services of qualified practitioners necessarily chose to use them on a regular basis. Indeed, throughout the eighteenth century the traditions of domestic and folk medicine remained very strong, while resort to unqualified practitioners was also common even

\footnotetext{
5 See, for example, Roy Porter, Disease, medicine and society in England, 1550-1860, London, Macmillan, 1987, p. 34; Jacques Léonard, Les médecins de l'Ouest au XIXème siècle, vol. 1, Paris, Honoré Champion, 1978.

'Claude Bruneel, 'Le livre de comptes d'un chirurgien rural en Brabant (1758-1788)', Bijdragen tot de Geschiedenis, 1979, 62: 255-65, on p. 261; For England see, for example, Margaret Pelling, 'Occupational diversity: barber-surgeons and the trades of Norwich, 1550-1640', Bull. Hist. Med., 1982, 56: 484-511.

${ }^{7}$ John V. Pickstone, 'The professionalization of medicine in England and Europe: the state, the market and industrial society', in Teizo Ogawa (ed.), History of professionalization of medicine, Proceedings of the 3rd International Symposium on the Comparative History of Medicine-East and West, Shizuoka, The Taniguchi Foundation, 1978, pp. 33-59, on p. 35. See also Hilary Marland, Medicine and society in Wakefield and Huddersfield, 1780-1870, Cambridge University Press, 1987, pp. 366-8.

${ }^{8}$ Waddington, op. cit., note 3 above, pp. 180-6.

${ }^{9}$ For Belgium, for example, see Chris Vandenbroeke, 'De medische consumptie sinds de 16de eeuw', Handelingen der Maatschappij voor Geschiedenis en Oudeidkunde te Gent, Nieuwe Reeks, 1980, 34: $143-65$.
} 


\section{R. M. J. Schepers}

amongst those sections of the population who could afford professional care. Indeed, the well-off considered restrictions on consulting whichever practitioner they deemed useful an assault on their freedom. ${ }^{10}$ The third major characteristic of the medical care business during this period was that there was no national market for it, but rather a series of loosely connected, more or less independent, local ones. This was reflected in the presence of a number of purely local guilds and companies, each of which was concerned with the regulation of only one particular branch of practice in its own locality. One striking contrast with the English situation is that the collegia medica, based in the main Belgian towns, granted licences to members of all medical occupational groups. After licensing by the collegia medica, surgeons and apothecaries were separately admitted to their respective guild or company. ${ }^{11}$ Although the two oldest collegia medica, in Antwerp (1620) and in Brussels (1650), were at first exclusively composed of university-trained physicians, by the eighteenth century there is little evidence in the formal regulations to suggest that physicians still dominated the collegia medica. Unlike the surgeons and the apothecaries, who were affiliated to their particular guild or company, physicians had no corporate organization of their own.

The collegia medica had considerable formal powers. They granted licences to practise medicine, surgery, pharmacy, and midwifery, and examined surgeons, apothecaries, and midwives. They drew up lists of registered practitioners and apprentices. The collegia medica supervised medical practice and some even obtained the right to discipline offenders for not respecting the established division of labour and for disloyal behaviour towards other practitioners. They were responsible for implementing public health measures, such as acting against contagious diseases and epidemics. Finally, they were obliged to supervise the provision of medical care for the indigent. However, there were limits on their powers. Collegia medica were established in only ten Belgian towns. ${ }^{12}$ The scope of their power was essentially local. ${ }^{13}$ They initially had no legal power to enforce their regulations beyond the town borders. In the eighteenth century, attempts seem to have been made to give the collegia medica influence over neighbouring rural areas, but with few practical results. ${ }^{14}$ Even in the towns, their influence seems to have been rather ineffective. For example, the chronicles of the colleges in Brussels and Antwerp make it clear that the apothecaries and surgeons resented control by the collegia medica, and successfully resisted encroachment into their affairs. Conflicts between the collegia

\footnotetext{
${ }^{10}$ Corneille Broeckx, Histoire du collegium medicum Bruxellense, Antwerp, Buschmann, 1862, p. $302,418$. More generally, see Porter, op. cit., note 5 above, pp. 44-7.

"For example in Ghent, surgeons passed a theoretical examination before the collegium medicum and a practical test before the surgeon's guild. E. G. R. Ossieur, 'J. B. Jacobs, chirurgijn, verloskundige en auteur (1734-1790)', Handelingen der Maatschappij voor Geschiedenis en Oudheidkunde te Gent, Nieuwe Reeks, 1972, 26: 69-91, on p. 77. See also L. J. Vandewiele, 'Vergelijkende studie over de collegia medica in België', Pharmaceutisch Tijdschrift voor België, 1956, 33: 145-64.

12 Antwerp (1620), Brussels (1650), Ghent (1664), Kortrijk (1683), Mechelen (1699), Liège (1699), Dendermonde (1754), Bruges (1760). According to Vandewiele, collegia medica were also established in Ypres and Tournai. The precise years of foundation are unknown, and the records were destroyed during the First World War. L. J. Vandewiele, Geschiedenis van de farmacie in België, Beveren, Orion, 1981, pp. 207-8.

${ }^{13}$ See, for example, Broeckx, op. cit., note 10 above, p. 87.

${ }^{14}$ For example, 'Décret de Charles VI maintenant à neuf florins la taxe à payer au collège des médecins de la ville de Gand par ceux qui subiront un examen devant ce collège pour exercer la chirurgie dans la châtellenie du Vieux-Bourg et les métiers d'Assenede et de Bouchoute, Bruxelles, 17 novembre 1724', Receuil des Ordonnances des Pays-Bas Autrichiens (hereafter RO), 1724, vol. 3, p. 448.
} 


\title{
The Belgian medical profession in the nineteenth century
}

medica and the apothecaries were more than once settled simply because the collegia medica had insufficient funds to prosecute. ${ }^{15}$

By the end of the eighteenth century, the significance of the traditional professional divisions was being eroded. Scientific progress, particularly in surgery, made the ancient boundaries between medicine and surgery increasingly irrelevant. While the ideas and attitudes of the Belgian corporations and collegia medica at the end of the century are not clearly known, one can hardly avoid the impression that the breakdown of licensing and regulation by the collegia medica and the local guilds was being encouraged by central government. For example, in 1787 the Austrian Emperor, Joseph II, abolished the monopoly of the University of Louvain to grant medical degrees within the Habsburg Netherlands and made the degrees of other Habsburg universities of equal status. ${ }^{16} \mathrm{He}$ also attempted to reform the Louvain medical faculty by emphasizing the importance of surgery and midwifery, prolonging the duration of studies, increasing the number of professors, and reducing the cost of medical education. He wanted to raise the educational level of town and rural surgeons and to have the medical faculty examine them in the future. The monopoly of the traditional institutions in admitting candidates for practice was undermined by an ordinance granting surgeons of the Viennese Academy of Surgery the right to practise in the Austrian Netherlands without any interference from the collegia medica and guilds. ${ }^{17}$ The erosion of traditional structures was linked to a new conception of the role of the state. The Dutch physician Gerard van Swieten, an advisor in matters of health care to the Austrian Empress, Maria Theresa, wanted

\begin{abstract}
to eliminate those special liberties, that ignorance and stultifying incompetence, which impeded enlightened government. If the state was to defend itself from its formal enemies, if it was ever to achieve internal efficiency, it would have to do away with selfish and separatist corporations, with faculties that taught useless knowledge and resisted new ideas, with apothecaries that dispensed incorrect drugs and threatened the lives of the citizens ... A self-sufficient, unified, and effective state could afford neither divisions nor stupidity. ${ }^{18}$
\end{abstract}

The reforms planned by the Habsburg monarch were never implemented because of the Brabant Revolution (1789-90), a short-lived revolt of the Belgian provinces against Habsburg rule. This revolution was precipitated by the reforms of Joseph II, which violated medieval charters of provincial and local liberties. A real revolution in medicine was brought about by the French. In France, all existing institutions were abolished by the Decrees of 2 March 1791 and 18 August 1792, and these were extended to the Austrian Netherlands after the victory at Fleurus on 26 June 1795. The University of Louvain was

\footnotetext{
${ }^{15}$ Broeckx, op. cit., note 10 above; Corneille Broeckx, Histoire du collegium medicum Antverpiense, Antwerp, Buschmann, 1858.

16 'Lettres circulaires addressées aux magistrats, ordonnant que les gradués de n'importe quelle université des pays de la domination impériale, ayant obtenue soit la licence, soit le doctorat dans une des trois facultés de théologie, droit ou médecine, jouissent des mêmes droits et privilèges que ceux de l'université de Louvain', Brussels, 2 janvier 1787, RO, 1787, vol. 13, p. 4.

17 'Ordonnance autorisant les étudiants de l'Académie de Chirurgie de Vienne après y avoir obtenu les diplômes prescrits, à exercer leur art en Belgique sans autres formalités, Brussels', 23 October 1789, RO, 1789, vol. 15 , p. 216 , and, 'Décret de l'Empéreur concernant les chirurgiens diplômés à Vienne, 23 octobre 1786', $R O, 1786$, vol. 12 , p. 547.

${ }^{18}$ F. T. Brechka, Gerard van Swieten and his world, 1700-1772, The Hague, Nijhoff, 1970, pp. 4, 149-51.
} 


\section{R. M. J. Schepers}

liquidated on 25 October 1797, and the major collegia medica and guilds dismantled. This caused a crisis, because the supply of qualified medical personnel was cut off, and the way opened to quacks and anyone else willing to pay a small tax to the government to obtain the right to practise. Yet, only in the case of pharmacy were formal regulations restored shortly thereafter, a response to the greater number of abuses. In France, the exigencies of war led to the resumption of formal medical education as early as 1794, with the establishment of medical schools at Paris, Strasbourg, and Montpellier. But Belgium had to wait until 1806 for the establishment of practical courses for the training of health officers for the army. ${ }^{19}$ University education only resumed after 1815 . In the major Belgian cities, learned societies were established, often with a mixed membership of physicians, surgeons, and apothecaries. Open medical practice, however, was not tolerated for long, and in 1803 a law brought medical training and practice under central control and subject to standardized, as well as simplified, procedures. Furthermore, the distinction between the two orders, that is doctors of medicine and doctors of surgery, on the one hand, and health officers, on the other, became more important than the distinction between medicine and surgery. Within the first order, surgery gained professional parity with medicine whereas in the second the combination of medicine and surgery was, as it had always been, the rule. This distinction between two orders was repeated in pharmacy and midwifery. The preservation of the second order-a controversial issue-was mainly justified by the poverty of the rural areas. Health officers were to be a kind of general practitioner for the masses. ${ }^{20}$ The law of 1803 consisted mainly of the regulation of medical training and admission to medical practice and was vague in spelling out the demarcations between the two types of medical practitioners and in defining their respective functions. Theoretically, the practitioners of the second order were responsible for the cure of minor diseases and ailments. In practice, they did more or less the same work as the universitytrained but equipped with less theoretical education. The law of 1803 compelled all qualified medical practitioners to register and to submit to patent regulations.

\section{MEDICAL PRACTICE IN THE UNITED KINGDOM OF THE NETHERLANDS IN THE EARLY NINETEENTH CENTURY}

The Congress of Vienna gave the Prince of Orange, later King William I, sovereignty over the Southern Netherlands. In 1815, a government commission was charged with the harmonization of medical legislation between the north and the south of the country. The usefulness and feasibility of allowing the combined practice of the various branches of medicine was one of the main issues of debate. Even though the commissioners acknowledged the impossibility of making clear demarcations between medicine, surgery, and obstetrics, they opted for the preservation of the old divisions mainly because the field of medicine was considered too broad for anyone to gain competence in every part of it. Therefore, division of labour combined with obligatory interprofessional consultation was

\footnotetext{
${ }^{19}$ Auguste Merckx, 'Les origines de la faculté de médecine de l'Université Libre: les cours practiques et l'école de médecine de Bruxelles de 1806 à 1834', Revue de l'Université de Bruxelles, 1925-26, 31: 38-91; Liliane Wellens-de Donder, 'Les sources de l'histoire de la médecine à Bruxelles pendant l'occupation française', Annales de la Société Royale d'Archéologie de Bruxelles, 1962, 51: 271-8.

20) Jacques Léonard, La médecine entre les savoirs et les pouvoirs. Histoire intellectuelle et politique de la médecine française au XIXe siècle, Paris, Aubier, 1981, p. 47.
} 
considered the best way to assure the quality of medical practice. However, this kind of specialization was judged to be practicable only in the major towns, where a sufficient clientele could secure a decent living for every practitioner. In the smaller towns and rural areas, only combined practice was possible because of the low population density, poverty, and the entrenched customs of the people. To rule otherwise, it was argued, would lead to an even greater shortage of qualified medical men and hence to charlatanism. Basically, the position taken was that it was preferable to have incomplete care rather than bad care or no care at all. As noted above, similar considerations played a role in the preservation of the second order of practitioners in France. The government commission was in favour of a clear separation between medicine and pharmacy. Again, the commissioners made allowances for the special conditions of the rural areas and smaller towns, where the survival of a practice depended on the ability to dispense, and where poverty and long distances made combined practice more or less inevitable if adequate medical care was to be provided. Therefore, the combination of medicine and pharmacy was allowed in rural areas and in towns without a local medical board. These boards could be formed only in towns with at least four doctors of medicine or surgery, but their establishment was never made obligatory. The initiative was left to the local authorities, who were also responsible for financing the boards. In fact, this provision led to combined practice being permitted everywhere except in the larger cities.

The new law on the practice of medicine for the Southern Netherlands was enacted on 12 March 1818. The medical practitioners who had graduated in the Austrian and French eras maintained their rights to practise. The law recognized the following types of medical practitioners: doctors of medicine, doctors of surgery, doctors of obstetrics, doctors of pharmacy, town surgeons, rural surgeons, naval surgeons, man-midwives and midwives, apothecaries, and druggists. The practitioners' rights and duties were differentiated according to whether they were university trained or not, according to the branch of medicine they practised - medicine, surgery, or obstetrics - and according to the location of their practice-town, countryside, or ship. It is worth emphasizing that the act did create a clear legal boundary separating the qualified from the unqualified. In contrast to the 1858 Medical Act in the United Kingdom, unqualified practice was made illegal.

The law of 1818 also established provincial medical boards. There was an obvious continuity with the collegia medica of the ancien régime. Nevertheless, the boards were new institutions expressing the central government's movement towards centralization, more uniform administration, rationalization and efficiency in various fields of social life. The board members were chosen by the minister from the most prominent physicians, surgeons, obstetricians, and apothecaries in the province. Recruitment within a small group of peers was, therefore, not excluded. The revenue of the boards came from the exchequer and, until 1835 in Belgium, from examination fees. The boards were

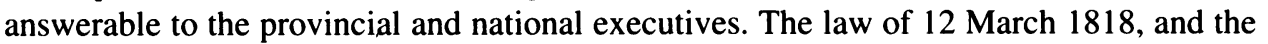
royal decree of 31 May 1818 implementing this law, gave considerable power to the provincial medical boards. They became responsible for the examination of non-university educated medical practitioners, certification of all medical diplomas, and the registration of officially recognized medical practitioners. Medical registers, listing the names of all those qualified, had to be submitted annually to the minister. These lists were intended to enable the provincial medical boards and the courts to distinguish between those who were 


\section{R. M. J. Schepers}

qualified and those who were not. Only those who were registered had the right to practise medicine. The provincial medical boards had to enforce the law in medical practice, although for this purpose they received only limited disciplinary power, and the prosecution of offenders was carried out by ordinary courts of law. Finally, the boards were responsible for the organization of health care in rural areas, for the care of the indigent, for the supervision of non-university medical schools, for the encouragement of vaccination, and for taking action in epidemics and outbreaks of contagious diseases. The government, however, failed to provide adequate means to carry out this impressive mission.

It is tempting, on the one hand, to consider the law of 1818 as an important legislative landmark for the Belgian medical profession. After all, it was replaced only in 1967. In 1818 , practitioners were accorded a monopoly of the provision of particular services in the market. The provincial medical boards represented the first step towards a system where medical practice was regulated on a national instead of a local level. One could even argue that with the provincial medical boards, the institutional basis of the modern structure of professional self-regulation was in principle, though not in practice, established. Indeed, the boards were exclusively composed of professionals, albeit from different branches of medical practice. But on the other hand, as will be illustrated, the law was only the first step in a process of securing autonomy that encompassed the whole of the nineteenth century.

\section{DEVELOPMENTS IN LEGISLATION AFTER BELGIAN INDEPENDENCE IN 1830}

\section{(1) The Institutional Development of the Belgian Medical Profession}

Following Belgian independence, the most important policy-making body was the Académie Royale de Médecine (1841). Its role was to advise the government on health and medical matters and to promote the scientific advancement of the various branches of the medical profession. The Académie was constituted of high ranking members of the Belgian medical, pharmaceutical, and veterinary professions. University professors, professors of the veterinary school, army doctors, members of the provincial medical boards, and some government officials were elected by the Académie, and subsequently became government appointees. Medical doctors formed a large majority, and all members were urban-based. ${ }^{21}$

A number of local professional associations, some medical journals, such as the Gazette Médicale Belge and Le Scalpel, and, after 1863, the national organization, the Fédération Médicale Belge (FMB), launched vigorous attacks upon the medical establishment and denounced it for incompetence, abuses, and undemocratic practices. The essence of the criticism was that the Académie was an élite organization with little desire to defend the interests of the majority of medical practitioners and with no concern for their problems and difficulties. The Académie, the government's most important

\footnotetext{
${ }^{21}$ Rita Schepers, De opkomst van het medisch beroep in België. De evolutie van de wetgeving en de beroepsverenigingen in de 19e eeuw, Amsterdam, Rodopi, 1989, p. 84; Carl Havelange, Les figures de la guérison (XVIIle-XIXe siècles). Une histoire sociale et culturelle des professions médicales au pays de Liège, Paris, Société d'Edition "Les Belles Lettres", 1990, pp. 283, 297, 300.
} 


\section{The Belgian medical profession in the nineteenth century}

advisory board in medical affairs, was an impediment to the local associations, and to the FMB, because its chief concerns related not only to scientific development but also to professional issues such as the future of the provincial medical boards, the usefulness of disciplinary councils, the dispensing of medicines by physicians in rural areas, educational reforms, the organization of care for the indigent, and so on. In such affairs, the Académie was not considered competent or representative.

In 1835, the provincial medical boards largely lost their influence over education but maintained all other prerogatives. There was a clear parallel between the criticism levelled against the Académie and that directed against the boards. Much of it centred on the control of medical practice by medical men, who were considered élitist and unrepresentative. $^{22}$ This issue will be examined in more detail in the third section. A third official institution, the Conseil Supérieur d'Hygiène Publique (1849), which was more concerned with public health matters than regulating professional affairs, will not be discussed here.

Finally, the development of professional associations from the 1840 s onwards, symptomatic of a growing professional consciousness among mid-nineteenth-century Belgian medical practitioners, must be considered. The first local medical associations for the defence of the moral and material interests of their members were set up in the early 1840s. They differed from the learned societies established during the French Revolution in being less élitist and concerned with a wider range of issues than the advancement of science. The stimulus for the establishment of professional associations came from a middle group of mainly university-educated physicians. Neither the prestigious, wealthy, and influential doctors of the Académie Royale de Médecine, the provincial medical boards and the medical faculties, nor the non-university educated medical practitioners contributed much to the establishment of the professional associations. Soon steps were taken to create a national association that would speak on behalf of the whole profession and defend the views of the "majority of medical men", as distinct from the Académie and the boards which were regarded as being dominated by the élite and their particular concerns. According to some reformers, the new organization was to be established on democratic principles with the members of the council being elected by all medical practitioners. Its relationship to the Académie would be similar to the relationship between the Chamber of Representatives and the Senate. ${ }^{23}$

A long and difficult struggle ensued. Divisions between medical practitioners working in the larger cities and those working in small towns and rural areas, between Flanders and Wallonia, between the capital, Brussels, and other major cities, as to the precise agenda for the reforms they wished to bring about delayed the establishment of a national organization of medical practitioners for many years. In 1863, a national association, the Fédération Médicale Belge, was finally established. The FMB brought together medical associations instead of individual practitioners, ${ }^{24}$ yet it was slow to consolidate its

\footnotetext{
${ }^{22}$ Schepers, op. cit., note 21 above, pp. 88-9; Havelange, op. cit., note 21 above, p. 395.

${ }_{23}$ Gazette Médicale Belge, 31 October 1847, p. 5.

${ }^{24}$ According to Le Scalpel, "profitant de la triste expérience faite par leurs devanciers, ils ne s’adressèrent plus aux médecins individuellement mais aux diverses associations locales éparpillées dans tout les coins du pays", Le Scalpel, 18: 17 September 1865.
} 


\section{R. M. J. Schepers}

position. Information on the exact number of FMB members is not available. In 1865, the organization was said to unite thirty-four associations with an estimated membership of 1,000 out of approximately 1,900 medical practitioners (53 per cent). ${ }^{25}$ In 1901 , it represented forty-one associations with a total membership of 1,767 out of 3,676 medical practitioners (48 per cent). ${ }^{26}$ More importantly, at the end of the century medical unions in the major cities, such as Brussels and Liège, tended to remain independent of the FMB. ${ }^{27}$ Nevertheless, in spite of the continuing lack of representativeness, of internal coherence and consensus, and the passivity and inertia of its members, the organization gained increasing recognition in government circles from about the 1880 s onwards. Without doubt this reflected the growing interest of the government in promoting new public health policies and programmes.

The Fédération Médicale Belge had one major objective on its agenda, the abrogation of the "antiquated" Dutch law of 1818. More particularly, the FMB demanded first the reform of the provincial medical boards with the aim of making the profession more self-governing, and second, continued permission for practitioners in rural areas to dispense medicines. The latter issue will not be discussed here. ${ }^{28}$ Other important concerns were the organization of medical relief in rural areas which was still grossly inadequate, and the struggle against quackery.

The FMB was established late compared with, for example, the Dutch medical association, the Nederlandsche Maatschappij tot Bevordering der Geneeskunst (the NMG, the Dutch Society for the Promotion of Medicine), which was founded in 1849. The integration of the majority of the Belgian medical élite within government institutions and medical faculties could have been one of the factors which slowed down the formation of a national professional association. Moreover, this integration could help to explain why the FMB, once established, took on the strategies of a trade union, in marked contrast with the occupational tactics of the Dutch professional organization in this period. The FMB's effort was first and foremost a struggle with the medical élite for a more equitable division of power within the medical profession, and was closely related to efforts to secure or improve the material position of Belgian practitioners. The NMG, in contrast, was itself a rather élitist organization. ${ }^{29}$ Between 1855 and 1865 , it represented a minority (around 37 per cent) of predominantly university-trained practitioners. A group of liberal, reformist, social minded men within its council determined the objectives of the organization, and its main goals included the unification of the Dutch profession and the reform of higher education. This reform was considered necessary to enhance the social standing of the Dutch profession and to improve the quality of care for the population. The

\footnotetext{
${ }^{25}$ Schepers, op. cit., note 21 above, p. 160. Lower figures are given by Velle: approximately 900 out of 1,700 Belgian medical practitioners (53 per cent). Karel Velle, 'Het verenigingsleven van de Belgische geneesheer (19de en begin 20ste eeuw). Een bijdrage tot de geschiedenis van het artsenberoep', Annalen van de Belgische Vereniging voor de Geschiedenis van de Hospitalen en de Volksgezondheid, 1988-89, 26-27: 47-118, on p. 92.

${ }^{26}$ Velle, op. cit., note 25 above, p. 92.

${ }^{27}$ Schepers, op. cit., note 21 above, pp. 163-4.

${ }^{28}$ For more details, see Rita Schepers, 'Pharmacists and medical doctors in nineteenth century Belgium', Sociology of Health and Illness, 1988, 10: 68-90.

${ }^{29}$ Mart J. Van Lieburg, "“De tweede geneeskundige stand" (1818-1865). Een bijdrage tot de geschiedenis van het medisch beroep in Nederland', Tijdschrift voor geschiedenis, 1983, 96: p. 448.
} 
council of the NMG also considered the reform of the provincial medical boards necessary, but at the same time emphasized their role in the protection of public health. ${ }^{30}$

\section{(2) Education and Entry to the Profession}

In this section, I will discuss the early abolition of the second order of medical practitioners, and the legal unification of the Belgian medical profession which was a particularly heterogeneous group, a result in part of the radical changes undergone by political and legal regimes within a short period of time. For example, in 182036 per cent of doctors of medicine in the province of Antwerp and 48 per cent in the province of Southern Brabant had graduated outside Belgium. In both provinces, about 50 per cent obtained their degrees prior to the French Revolution. ${ }^{31}$ The structural differentiation between university and non-university education was an even more important cause of the lack of internal coherence in the "medical profession" at the beginning of the nineteenth century. Non-university education was shorter and less expensive and, therefore, more attractive to candidates from lower social classes. Upon completion of their studies, non-university graduates had almost the same rights and obligations as their universityeducated colleagues. This affected the income and prestige of university graduates, and called into question their claims to greater skill and knowledge. Moreover, both the universities and the provincial medical boards tried to recruit as many candidates as possible which made control of the supply of medical practitioners difficult. It was argued that this dual educational system led to the overcrowding of the profession and to serious difficulties in establishing a practice. ${ }^{32}$ There may have been some substance to these complaints. In the brief interval between 1830 and 1835 , a period of freedom of education, many people allegedly made use of the situation to obtain a degree, preferably a university degree in medicine. As a consequence there was a rapid increase in the number of medical practitioners. ${ }^{33}$ The abrogation of non-university medical education by the law of 27

\footnotetext{
${ }^{30)}$ Eddy Houwaart, 'Hygiënisten in de 19e eeuw I. Een wetenschappelijk gefundeerd streven naar reorganisatie van de Nederlandse samenleving', Tijdschrift voor Sociale Gezondheidszorg, 1983, 61: 258-65; idem, 'Hygiënisten in de 19e eeuw II. Hygiënisten en de geneeskunde als sociale wetenschap en anthropologie', Tijdschrift voor Sociale Gezondheidszorg, 1983, 61: 295-308; idem, 'Hygiënisten in de 19e eeuw III. De hervormingsstrategie van de hygiënisten in Nederland in de $19 \mathrm{e}$ eeuw', Tijdschrift voor Sociale Gezondheidszorg, 1983, 61: 335-49; idem, De hygiënisten. Artsen, staat en volksgezondheid in Nederland 1840-1890, Groningen, Historische Uitgeverij, 1991, p. 95.

${ }^{31}$ Rita Schepers, 'De opkomst van het Belgisch medisch beroep. De evolutie van de wetgeving en de beroepsorganisatie in de 19de eeuw', PhD diss., University of Leuven, 1983, p. 235. Degrees were obtained in Leyden, Paris, Vienna and Strasbourg.

${ }^{32}$ For example, according to Van Esschen, professor of the school of medicine in Brussels, university educated medical practitioners would also settle in rural areas "dès qu'ils [les médecins] ne seraient plus réduits à y lutter [avec les officiers de santé], non par le savoir mais par la modicité des honoraires; dès qu'ils ne verraient plus les privilèges qu'ils ont obtenu par de si longues études et des sacrifices si nombreux, usurpés par des hommes qui ont été exempts des unes et des autres", Van Esschen, Lettre à M. Lesbroussart sur l'état actuel de l'enseignement médical et sur les moyens de l'améliorer, Bruxelles, Ode et Wodon, 1831, pp. 22-3. See also les professeurs de l'École de Médecine de Bruxelles, A Messieurs les Membres de la Représentation Nationale, Bruxelles, 1834; Fallot, 'Réflexions sur quelques points de la législation médicale en vigueur en Belgique', Encyclographie des Sciences Médicales, le Bulletin Médical Belge, 1834, 19-20: 74; C. Houdet and P. J. Wouters (eds), Projet de loi sur l'enseignement médical donné aux frais de l'Etat en Belgique, Bruxelles, P. J. Voglet, 1835.

${ }_{33}$ Exposé de la situation du Royaume (1841-1850), Bruxelles, Th. Lesigne, 1852, p. 319; Beatrijs Van Der Schueren, 'De faculteit van geneeskunde aan de staatsuniversiteit te Leuven', MA thesis, University of Leuven, 1963, p. 94; Corneille Broeckx, Coup d'oeil sur les institutions médicales Belges depuis les dernières années du l8e siècle jusqu'à nos jours, suivi de la bibliographie de cette époque, Bruxelles, Société
} 
September 1835 undoubtedly favoured university graduates, but it was not only self-interest that was behind the early abolition of non-university medical schools in Belgium. Although the processes which gave rise to this change are by no means wholly understood, some of the following factors probably played a role.

It is striking that in Belgium around 1830 the second order was only slightly stronger numerically than the first (47 per cent university trained) whereas in the Netherlands a decade later, in 1842, only 37 per cent of medical practitioners had acquired a university degree. ${ }^{34}$ Moreover there are some indications that in certain provinces, such as Southern Brabant and Liège, university graduates settled in increasing numbers in rural areas. ${ }^{35}$ This development undermined one of the main justifications for the preservation of a second order of practitioners. Indeed, French as well as Dutch legislators had judged it necessary to maintain a lower grade of practitioners to ensure health care for the masses, especially in the rural areas. In government circles, people were convinced that four universities guaranteed a sufficiently large number of medical practitioners for the country. ${ }^{36}$ Too many educational facilities would threaten the very existence of the university medical faculties. The decision to abrogate non-university education was also influenced by a greater appreciation of the university graduates' expertise and by the recognition of each patient's right to equal standards of care. As a result of the abolition of the second order, standards and also the expense of medical education were raised quite suddenly. This made entry into the profession more difficult and accentuated the difference between qualified and unqualified practitioners. From 1836 onwards, a university degree was required of new entrants to practise medicine.

The law of 15 July 1849, which introduced the degree of Doctor of Medicine, Surgery, and Obstetrics, was the last important step in the process of the legal unification of the Belgian medical profession. Two important debates on medical education were held in the Académie Royale de Médecine in 1842 and 1849. The Académie wished to raise the social standing of the profession by improving medical education. In 1842, the spokesman for the commission on medical education asserted in his presentation that the custom of combined practice was widespread and that many doctors with only one degree were practising generally, that is, combining medicine, surgery and obstetrics without proper qualifications. Therefore, they ran the risk of being charged by the provincial medical boards or the courts of law for illegal practice. In order to eliminate the possibility of incurring penalties, and because a ban on combined practice seemed unrealistic, it was preferable, according to the spokesman, to make sure that practitioners would have the right qualifications by training them in the three branches of medicine. He added that the distinction between medicine and surgery was quite undefinable and that surgical and

\footnotetext{
Encyclographique, 1841, p. 16. According to the Gazette Médicale Belge, 3: 9 February 1845, 754 candidates obtained the degree of doctor of medicine between 1831 and 1834, compared with only 253 between 1836 and 1841. The same phenomenon allegedly occurred for the lower degrees of medicine. Compared to official figures, these estimates seem grossly exaggerated.

${ }^{34}$ Van Lieburg, op. cit., note 29 above, p. 437; Schepers, op. cit., note 21 above, p. 141; Havelange, op. cit., note 21 above, p. 402.

${ }^{35}$ Schepers, op. cit., note 21 above, p. 75; Havelange, op. cit., note 21 above, pp. 225-6.

${ }^{36}$ Jules Sauveur, Histoire de la législation médicale belge, Bruxelles, A. Decq, 1862, p. 273. In 1835, four universities were officially recognized, that is two free universities (a Catholic one in Louvain, and a freethinking one in Brussels), and two state universities (Ghent and Liège).
} 
medical practice were indistinguishable. One of the counter-arguments was that, since practitioners would not devote their full attention to one branch in particular, they would be unable to become competent in any branch. Greater homogeneity would be reached at the expense of the expertise, the skill, and the status of the "specialized" practitioner. According to one speaker, a kind of rural practitioner was being created, and he added "vous savez qu'à cette dénomination se rattache, souvent à tort, une certaine défaveur, les médecins de campagne étant supposés moins instruits et moins habiles que ceux de leurs confrères qui exercent dans les villes". ${ }^{37}$ At a time of growing specialization, the proposed bill would be a step backwards. More pragmatically, it was argued that there was already a clear tendency to take a second qualification and that legal enforcement was, therefore, superfluous.

In 1842, a compromise was reached within the Académie: the distinction between doctor of medicine, on the one hand, and doctor of surgery and obstetrics, on the other, was introduced and conditions for combining all branches of medicine were facilitated. In 1849, the Minister of Internal Affairs contacted the Académie once more in connection with a draft bill on medical education that he was preparing. This again contained the concept of Doctor of Medicine, Surgery, and Obstetrics. The spokesman for the commission on medical education emphasized to the Académie the social importance of one class of medical practitioner, providing the same quality of care to all levels of the population. The proposal would also have important consequences for the medical profession because colleagues would no longer be part of a hierarchical order. The aim was to train all doctors as safe general practitioners before they proceeded to qualify as specialists. This time, the draft bill was accepted by the Académie without many difficulties. In general, the law was welcomed by the medical press. Only the Gazette Médicale Belge labelled it superfluous because an increasing number of medical students already took a second qualification. Therefore, "il nous manquera jamais de general practitioners". 38

The laws of 1835 and 1849 had the following consequences for the medical profession. First, a more homogeneous and uniform educational system was created. The process of medical education became a relatively standardized one in which all students were subjected to broadly similar influences. All medical students now received their education at universities; all had to pass an examination in medicine, surgery, and obstetrics. Shared experiences with other students may well have facilitated the development of a common professional identity. With regard to medical practice, all future graduates were to possess a common university degree, enjoy the right to practise all branches of medicine, and were awarded the same title. Already by 1860,80 per cent of all medical practitioners were university trained. This led to a decrease in the number of violations of medical laws and of conflicts over the division of labour. The overall density of medical practitioners decreased from 4.79 per 10,000 in 1831 to 3.79 per 10,000 in $1875 .{ }^{39}$ The fall in numbers

\footnotetext{
${ }^{37}$ Bulletin de l'Académie Royale de Médecine, 1842, 1: 295.

${ }^{38}$ Gazette Médicale Belge, 7: 27 May 1849.

${ }^{39}$ Exposé de la situation du Royaume (184/-1850), Brussels, Th. Lesigne, 1852, p. 520; Exposé de la situation du Royaume (1876-1900), Brussels, 1901, p. 160. These figures seem very low compared with the figures given by Waddington for 1861 in Britain, namely 7.1 doctors per 10,000 population. Waddington, op. cit., note 3 above, p. 149. However, following Gelfand, it could well be that Britain was exceptional at least compared to
} 


\section{R. M. J. Schepers}

may have boosted incomes and, as a consequence, raised social selection and prestige, but whether a restriction of entry caused medical incomes to increase still has to be ascertained. In the mid-nineteenth century, Belgium was in severe economic crisis and this could well have offset any rise in income, but there is, alas, no information on the financial situation of medical men during this period. The subsequent rise after 1875 in the overall density of medical practitioners can be attributed to the increasing numbers of university trained doctors who compensated for the fall-off in non-university trained practitioners. In addition, the reform of the law on higher education in 1876 made access to medical education easier. But, according to Havelange, the rise was above all due to the growing prestige of medicine at the end of the century. ${ }^{40}$

Table 1

Number and density of medical practitioners in Belgium in the years 1831 to 1900

\begin{tabular}{lclll}
\hline & Doctors & Surgeons & Total & $\begin{array}{l}\text { Density of medical practitioners } \\
\text { per 10,000 population }\end{array}$ \\
\hline 1831 & 864 & 952 & 1,816 & 4.79 \\
1840 & 1,221 & 879 & 2,100 & 5.15 \\
1850 & 1,257 & 658 & 1,915 & 4.37 \\
1860 & 1,507 & 377 & 1,884 & 3.98 \\
1875 & 2,048 & - & 2,048 & 3.79 \\
1900 & 3,544 & - & 3,544 & 5.29 \\
\hline
\end{tabular}

Source: Exposé de la situation du Royaume (1841-50), p. 521, (1851-60), p. 318, (1876-1900), vol. 2, p. 160.

The developments thus far can be summarized as follows. In 1818, it was stipulated that only registered practitioners could legally practise medicine. From 1836 a university degree was required before registration, and from 1849 there was a common university degree for physicians, surgeons, and obstetricians. By 1849 a legal monopoly was established for one unified group of university-trained practitioners. However, it needs to be emphasized, first, that neither of these laws effectively excluded the unqualified from practice, and, second, that the Belgian profession was never completely autonomous in regulating medical education. Political rivalry between the Liberal and Catholic parties made university education a hotly debated issue. This debate affected, for instance, procedures regulating entrance to universities and examinations. Leaders of the medical faculties and the Fédération Médicale Belge alike bemoaned the low level of general education among medical students due to the lenient university entrance requirements. Enrolments in medical faculties were not limited, and, despite the decreasing density of practitioners, complaints about professional overcrowding continued to be heard. The excessive numbers were considered to be the result of the inadequate organization of university education. According to Havelange, this was a useful and powerful argument.

France, Germany and also Belgium. Toby Gelfand, 'The history of the medical profession', in W. F. Bynum and R. Porter (eds), Companion encyclopedia of the history of medicine, vol. 2, London, Routledge, 1993, pp. 1119-50, on p. 1135.

${ }^{40}$ Havelange, op. cit., note 21 above, p. 405. 


\section{The Belgian medical profession in the nineteenth century}

Parce que l'enseignement est le lieu favori des querelles politiques du temps, la critique des médecins est toujours recevable et crédible. La problématique de l'instruction dépasse les limites de son objet et devient, au XIXe siècle, le bouc émissaire de nombreuses tensions sociales, politiques et professionnelles. ${ }^{41}$

In fact, what the FMB defined as a problem of too many practitioners was really a problem of distribution. The majority of medical men flocked to the towns, leaving the rural areas undersupplied. It should also be stressed that the laws of 1835 and 1849 were enacted before the establishment of efficient professional associations. In neighbouring countries, one of the major objectives of the newly-founded professional associations, such as the Nederlandsche Maatschappij tot Bevordering der Geneeskunst, was to campaign for the unification of all branches of the medical profession. In Belgium, the professional élite in the Académie Royale de Médecine seems to have brought about this move towards unification. In a general sense, then, one could conclude that the medical profession gained control over the training of medical practitioners. It would be more accurate, however, to speak of control wielded by an élite segment, which was at that time by no means in tune with the wishes of the practitioners it trained at the universities.

After its establishment, the FMB tried in vain to have a greater say over entrance to the profession because it considered that the interests of the medical faculties did not coincide with those of practising doctors. Hence its attempts to take over the supervision of medical practice. To achieve this aim, the reorganization of the provincial medical boards and the establishment of disciplinary councils was considered crucial. In addition, the development of a code of medical ethics was regarded as a necessary supplement to this reform.

\section{(3) The supervision of medical practice}

According to medical practitioners in both the Netherlands and Belgium, the 1818 act was deficient in many essential respects, and the way the supervision of medical practice was organized was severely criticised. ${ }^{42}$ But, again, there were differences of emphasis. In the Netherlands, the NMG, and in particular its council, seems to have been more concerned with the consequences of this inadequate organization for public health. In Belgium, much of the criticism levelled against the provincial medical boards centred on the control of medical practice by medical men, appointed by the government, who were considered élitist and unrepresentative. The issue of appointments draws attention to a fundamental dissension within the medical profession, and probably in government circles as well, regarding the role of the government in internal professional affairs. There were two distinctly opposing views on this issue. According to one, defended mainly by the Académie and the provincial medical boards, the government was responsible for the entire health care sector, including professional practice. The provincial medical boards

\footnotetext{
${ }^{41}$ Carl Havelange, 'Pléthore et art de guérir. Le malaise des médecins Liégeois au XIXe siècle', Revue médicale de Liège, 1984, 39: 679.

${ }^{42}$ D. Cannegieter, Honderdvijftig jaar gezondheidswet, Assen, Van Gorcum, 1954, p. 49; C. C. Delprat, 'Het ontstaan der Nederlandsche Maatschappij ter bevordering der Geneeskunst en haar rol bij de herziening der geneeskundige staatsregeling van 1818, Gedenkboek der Nederlandsche Maatschappij tot Bevordering der Geneeskunst bij haar 75-jarig bestaan, 1924, pp. 27-9; Houwaart, op. cit., note 30 above, 1991, pp. 75-6; Schepers, op. cit., note 21 above, pp. 88-9; Havelange, op. cit., note 21 above, p. 308; pp. 395-6.
} 


\section{R. M. J. Schepers}

were first and foremost administrative bodies charged by the government with the control of medical practice in the general interest. Because of their official character, proponents of this position would not agree to members of the boards being nominated by the medical associations, and they insisted on appointment by the minister after consultation.

According to the second opinion, represented by the local medical associations, the legislator's main goal had to be the protection of the medical monopoly against the encroachment of unqualified practitioners, laymen and apothecaries, as well as against local authorities and charitable institutions. Here, the conventional argument was that medical education was an investment and that unqualified practitioners were denying those who were qualified a legitimate return on that investment. Moreover, unqualified practitioners were alleged to harm patients, though at the time probably neither qualified nor unqualified practitioners were particularly effective in curing ailments. Supporters of this view judged that the provincial medical boards were too preoccupied with carrying out their administrative tasks, were ineffective in the protection of licensed practitioners from competition of the unqualified, and were insufficiently concerned with the defence of doctors' rights and interests. Many claimed that the boards had degenerated into cliques whose members imagined themselves to be superior to their colleagues because of their disciplinary power. The medical practitioners protested that though they had completed long and difficult studies, they still had to suffer the patronizing attitude of these official institutions. The government's ultimate responsibility for the health care sector was not questioned. Government intervention was sometimes even actively solicited, for example, in the care of the indigent. However, in internal professional affairs government intervention had to be limited as much as possible. Therefore, it was requested that the provincial medical boards be made up wholly of elected representatives of the profession. The government would appoint these elected members in order to strengthen their authority.

In part, these two viewpoints reflected the social differences within the medical profession and the majority's opposition to what it considered the predominant role of a small number of élite physicians in the development of health care policy. In this respect, the movement for reform of the provincial medical boards can be considered as an attempt to remove the subordination of the masses of ordinary medical men to the élite. But the existence of disagreements within the élite concerning the role of the government in medical affairs suggests that a simple reduction of the problem to opposition between the élite and the rank and file is inadequate. The local professional associations, the Fédération Médicale Belge and some medical journals conducted a sustained campaign in favour of elections, which would bring about a shift in authority from the élite to the majority of medical practitioners. In order to enhance the likelihood of the election of members to the provincial medical boards, arguments were put forward favouring a clear-cut distinction between public health, considered as belonging exclusively to the government's jurisdiction, and the control of medical practice.

The Royal Decree of 31 May 1880 abolished the provincial medical boards' disciplinary power and extended their responsibility for public hygiene. This caused the FMB to change course. It feared that it would not be possible politically to obtain directly elected provincial medical boards with disciplinary powers. Therefore, its principle objective became the reduction of the board's authority over medical practice and the 


\section{The Belgian medical profession in the nineteenth century}

establishment of independent disciplinary councils, institutions that belonged entirely to the medical profession and that could act officially. This resulted in a lengthy campaign for autonomously elected disciplinary bodies, towards the end of the century to be labelled Order of Physicians, which was finally established in $1938 .{ }^{43}$ From the 1880 s onwards, the FMB was gaining ground within the government. Because the legislation of 1880 failed to bring about the intended improvement in public hygiene, a renewed attempt was made in 1895. This time, the Belgian government approved the principle of elections for some members of the provincial medical boards. The FMB welcomed the law as the first step in the right direction. The elections in 1895 brought representatives of the militant medical associations onto the boards, and according to one commentator,

La moralité à tirer de l'évènement est évidente et limpide. Le corps médical a nettement exprimé, par ses votes, le désir ferme qu'il a de poursuivre la réalisation de ses voeux, de ses désiderata. Que le gouvernement organise lui-même son corps d'hygiénistes . . . Mais qu'on nous abandonne à nous et à nous seuls, le soin de choisir les hommes chargés de veiller à la dignité et à la probité professionnelles, chargés de défendre nos intérêts. ${ }^{44}$

Finally, in 1899 a government proposal made a clear distinction between the protection of public hygiene and supervision of medical practice. The latter would become the exclusive task of fully-elected provincial medical boards. The willingness of the government to introduce these changes can be seen as evidence of the increasing influence of the FMB, and also of the shift in power from the élite to the professional associations. But the changing political and social climate no doubt had an effect too. At the end of the nineteenth century, the ideology of a corporate state, composed of diverse economic or functional groups was gaining ground within the ruling Catholic party in Belgium. For professional groups, the granting of a large degree of autonomy in the handling of their internal affairs became more acceptable in this political context, than in the midnineteenth century with its dominant liberal ideology. In the Netherlands on the contrary, major leglislation on the medical profession was issued under a liberal government in the 1860s. This could help explain the differences between the two countries. Moreover, the Belgian government's interest in the promotion of public health increased the power of the medical profession.

Professional associations regarded the defence of moral and material interests as closely related. Unfair competition between colleagues, allegedly due to the overcrowding of the profession, was considered to be one of the causes of the depressed levels of medical incomes. According to one member of the Académie "la haine des médecins est devenue proverbiale à côté de celle des dévots". ${ }^{45}$ Early medical journals such as the Gazette Médicale Belge had already tried to establish rules for regulating relationships between practitioners. These rules prohibited, for example, advertising, poaching of patients, undercutting of fees, and collaboration with unqualified practitioners. They also laid down the proper conduct for consultations. Local professional associations tried to enforce their

\footnotetext{
${ }^{4.3}$ For more details, see Rita Schepers, 'The Belgian medical profession, the order of physicians and the sickness funds', Sociology of Health and Illness, 1993, 15: 375-92.

${ }^{44}$ Le Scalpel, 47: 2 June 1895.

45 Bulletin de l'Académie Royale de Médecine, 1842-43, 2: 820.
} 


\section{R. M. J. Schepers}

professional codes, but this was considered ineffective since dishonest practitioners rarely became members of a professional association, or resigned as soon as they were sanctioned. Towards the end of the century, the FMB also developed a code of ethics. The overcrowding of the profession was explicitly mentioned as one of the reasons for drawing up professional rules. The concern was not primarily with regulating the behaviour of doctors towards their patients, but rather towards their fellow practitioners and the profession (specifically the FMB). The code was divided into three sections: obligations towards the medical profession, obligations towards colleagues, and, lastly, obligations towards the public. A physician's first duty was to join a professional association. These associations in turn were obliged to affiliate themselves to the FMB. Membership of the FMB's pension fund was also presented as a professional duty. Relatively little attention was devoted to the patient-practitioner relationship. Respect, honesty, patience, discretion and compassion were advocated. Rich and poor patients had a right to the same quality of care. Only a body with legally defined powers to discipline practitioners whose conduct fell below these minimum standards was still lacking. Hence, the importance of the reform of the provincial medical boards described above.

\section{CONCLUSION}

In this article we have focused on the professionalization of Belgian medical practitioners in the nineteenth century. In particular, two aspects of their autonomy have been studied: the development of control over entry to the profession, and collegial control over discipline. In Belgium (as in the Netherlands) legal monopoly and supervision of medical practice by professionals were established at an early stage. As the result of changes in medical education in 1835 and 1849 , the heterogeneous collection of medical practitioners evolved first legally and later in practice into a relatively homogeneous occupational group. However, in order to understand the dynamics of the professionalization of Belgian practitioners, one has to go beyond these formal characteristics and study the structural division between the élite and the rank and file. It is suggested in this article that, in the course of the century, important changes developed in the relationships between members of this unified medical profession which did not affect its legal position as a corporate body so much as its internal organization. Broadly speaking, education remained the province of the élite, with little interference from professional associations. In contrast, the supervision of medical practice and the setting of standards gradually shifted to the associations, in particular to the Fédération Médicale Belge. The FMB increasingly gained the means to model medical practice in accordance with its own goals and to promote private practice. In the introduction, it was suggested that the concept of autonomy has many dimensions. We have as yet no data on the economic autonomy of the Belgian medical profession, only persistent complaints that its economic situation was deteriorating. The involvement of professional associations in policy-making was only beginning to develop at the end of the nineteenth century. Whether the Belgian medical profession was autonomous in these other respects still has to be ascertained. In any case, the growing social prominence of medicine at the end of the century enhanced its power base, almost independently of its own successful tactics to enforce its position. 